International Journal of Engineering \& Technology, $9(1)(2020) 128-132$
International Journal of Engineering \& Technology
Website www.sciencepubco.com/index.php/IJET
Research paper

\title{
Ore resource modelling of Ajabanoko iron ore deposit, Ajabanoko, Nigeria
}

\author{
Adebimpe Rasheed Adeshina ${ }^{1 *}$, Akande Jide Muili ${ }^{2}$ \\ ${ }^{1}$ The Federal Polytechnic, Ado-Ekiti, Nigeria. Department of Mineral and Petroleum Resources Engineering \\ ${ }^{2}$ University of Namibia, Namibia. Department of Mining and Metallurgical Engineering \\ *Corresponding author E-mail: rasheed4ul@yahoo.com
}

\begin{abstract}
Ore resource modelling is an essential aspect of mining operation. It is also a crucial pre-mining step required for a successful exploitation of mineral deposits. Ajabanoko iron ore resource model was developed and the ore reserve estimate carried out using inverse distance method as contained in Surpac 6.4.1 mine software. The total number of blocks used for the model is 54,475. Ore estimation result obtained from thirteen drill hole data indicates $38,313,595$ tonnes of iron ore and density of 3.65 tonnes $/ \mathrm{m} 3$. The average grade and total volume of the ore body is $36.36 \%$ and $10,496,595 \mathrm{~m} 3$ respectively.
\end{abstract}

Keywords: Ajabanoko; Blocks; Drill Hole; Exploitation; Resource Modelling; Reserve Estimate.

\section{Introduction}

The application of computer software packages in recent times to ore resource modelling has greatly improved the economic evaluation of mineral resources. The use of a computerized system in certain Mine Software can calculate the reserves and even design a mine with a faster and better approach to calculating mineral deposits [1]. The economic evaluation of natural resources depends on the accuracy of reserve estimates [2]. Inputs such as borehole logs and topographic details of the deposit have increasingly become valuable tools in ore reserve estimation as a result of the computer softwares. Therefore high degree of accuracy must be maintained during data collection. This will consequently promote a reliable geological database. An understanding of the geology of a deposit is fundamental to the Mineral Resource Estimation (MRE) process, since estimates are constrained by the geological complexity captured within the geological model, usually based on geology, geometry, structural nature, and grade distribution of the deposit [3].

A Mineral Reserve includes diluting materials and allowances for losses that may occur when the material is mined [4]. The ultimate goal of mineral resource estimation is a numerical model that will accurately predict the tonnages and grades that will be extracted from a mining operation [5].

In the stages leading to the development of any deposit, an acquired mineral prospect is expected to yield areas of mineralization when subjected to geological investigation techniques [6]. Good estimation of this mineralization is the first step in assessing the economic merit of the venture and becomes the basis for mine planning during early years of production [6]. The three usually used techniques in computer aided ore reserve estimation are: nearest neighbour, inverse distance and kriging [7].

Hexahedral block models are widely used to simulate and classify resources [8]. State-of-the-art software uses algorithms that sequentially divide each block into smaller blocks in order to follow the geological structures (sub-blocking), but this approach does not achieve the level of precision required and results in models with an extremely high number of blocks [9]. Most of these methods are contained in widely available commercial mine design softwares and makes ore resource modelling relatively easier to accomplish. In this regard, the objectives of the study are to develop a resource model for Ajabanoko iron ore deposit and subsequently estimate the ore reserve.

\subsection{Geology of the ore deposit}

The study area for this research work is Ajabanoko, located in Okene, Kogi State, Nigeria. Ajabanoko iron ore deposit is on longitude $6^{0}$ 14' $0^{\prime \prime} \mathrm{E}$ and latitude $7^{\circ} 33^{\prime} 0^{\prime \prime} \mathrm{N}$ and lies $4.5 \mathrm{~km}$ Northwest of Itakpe hill.

The Ajabanoko deposit area falls within the Nigerian Precambrian basement complex, a suite of crystalline rocks exposed in over nearly half of the country extending west into Dahomeyan of Benin Republic and east into Cameroon [10]. The Ajabanoko area consists of a set of three closely related hills of basement rocks in which some large bands of iron ore occur. These three hills which mark the southern, central and northern ore zones are made up mainly of migmatite and biotite gneisses which trend in a northeast-southwest direction and dip mostly westwards. The dominant lithologic units of Ajabanoko deposit area are gneiss of migmatite, biotite and granite, ferruginous quartzites, granites and pegmatite [10]. The ferruginous quartzite is the source of the iron ore mineralization in the area [11]. 
The nature of Ajabanoko iron ore deposit and the associated rocks indicate that they are residual concentrates derived from iron rich sediment, a volcanogenic sedimentary material [12]. This suggests that all the rocks in the area including the high grade metamorphic ones, such as the gneisses and the low grade metamorphic ones such as the quartzites may have been derived from sedimentary materials which, in turn, were probably derived from an ancient volcanic source [13].

Four principal ore layers have been identified for the different ore zones [14]. Four thick bands ranging from $1 \mathrm{~m}$ to $5 \mathrm{~m}$ in thickness and measuring $1.22 \mathrm{~km}$ along strike have been identified in the deposit, and are classified as orebody I, orebody II, orebody III and orebody IV [13]. Petrologic studies of the ore have revealed four major types of ore composition similar to Itakpe Hill, Nigeria: (i) magnetite quartzites (ii) magnetite-hematite quartzites (iii) hematite-magnetite quartzite (iv) hematite-quartzite

Table 1 presents the parameters of the main ore layer of Ajabanoko iron ore deposit with an average ore thickness that varies from $3.6 \mathrm{~m}$ to $14.7 \mathrm{~m}$

Table 1: Parameters of the Main Ore Layer of Ajabanoko Iron Ore Deposit

\begin{tabular}{llll}
\hline Ore Layer & Length Along Strike $(\mathrm{m})$ & Average Thickness $(\mathrm{m})$ & Average $\mathrm{Fe}_{\text {tot }}$ \\
\hline Orebody I & 1100 & 14.7 & 40.4 \\
Orebody II & 925 & 10 & 30.3 \\
Orebody III & 750 & 3.6 & 37.28 \\
Orebody IV & - & 4.3 & 34.04 \\
\hline
\end{tabular}

National Steel Raw Material Exploration Agency [13].

From hydrological point of view, the elevation and geology favours fast drainage and insignificant accumulation of water within the confines of the deposit [14].

The only nearby river source is the Okurogo river which flows at $+200 \mathrm{~m}$ above sea level compared to the summits of the northern, central and southern ore zones at $+380 \mathrm{~m},+360 \mathrm{~m}$ and $+265 \mathrm{~m}$ respectively [14]. The geology and contour of Ajabanoko iron ore deposit are presented in Fig. 1.

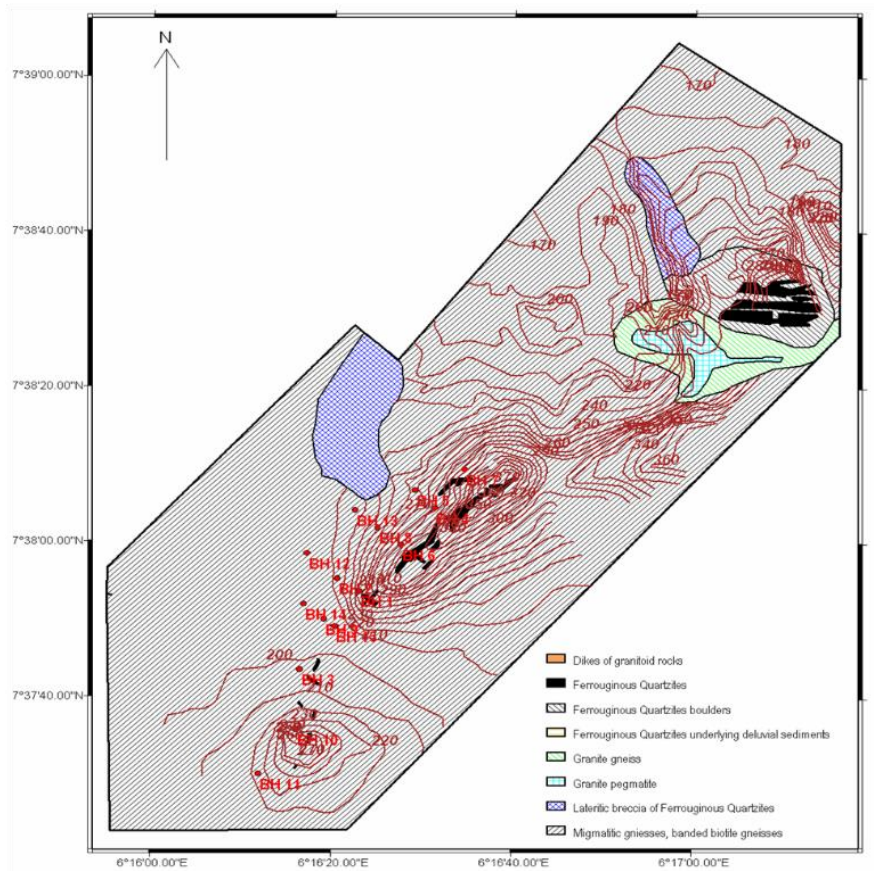

Fig. 1: Geology and Contour of Ajabanoko Iron Ore Deposit.

\subsection{Ore resource modelling methods}

A mineral deposit model is the systematically arranged information describing the essential attributes (properties) of a class of mineral deposits [15]. Traditional reserve estimation methods can be roughly classified into two main groups: geometric and geostatistical methods [16]. The geometric methods comprise the block methods (triangle, regular, squares, rectangular, polygonal and irregular or geometric blocks), the methods of profiles (vertical, horizontal and inclined) and the isopach method. The geometric block method (GBM) is one of the most popular methods for reserve estimation [17].

Geostatistical method involves a series of clearly identifiable stages which include; data review, statistical analysis, geological analysis, structural analysis, local estimation, global estimation and grade-tonnage curve [18].

Geostatistical methods can be used to determine: (i) the optimum sample size (ii) the optimum sample pattern(iii) the optimum sample density (iv) the area of influence of each sample which may be circular, elliptical, spherical or ellipsoidal (v) the nature of the mineralization, i.e. its characterization (vi) predictability of grades, thickness, etc [18].

\section{Methodology}

\subsection{Resource modelling}

Ore reserve estimate of the central region of the ore body of Ajabanoko iron ore deposit was carried out using thirteen boreholes. A geologic database was created. Text files such as survey table, assay table, geologic table and collar table extracted from the borehole logs 
were arranged in format acceptable to the SURPAC software, these were loaded into the database. Sectioning of the drill holes was carried out which led to the creation of closed strings. Parts of the Collar and Assay data are presented in Tables 2 and 3 respectively.

Table 2: Part of Ajabanoko Collar Data

\begin{tabular}{|c|c|c|c|c|}
\hline Borehole Number & $\mathrm{Y}$ & $X$ & $\mathrm{Z}$ & Maximum Depth \\
\hline $\mathrm{BH} 1$ & 844520.99 & 199121.95 & 255 & 129.99 \\
\hline BH1 & 844572.10 & 199047.25 & 215 & 128.75 \\
\hline BH1 & 844211.44 & 198919.25 & 203 & 151.50 \\
\hline BH1 & 844922.04 & 199311.67 & 256 & 85 \\
\hline BH1 & 844704.76 & 199264.14 & 280 & 115.5 \\
\hline
\end{tabular}

Table 3: Part of Ajabanoko Assay Data

\begin{tabular}{|c|c|c|c|c|}
\hline Borehole Number & Sample Number & $\mathrm{m}$ from & $\mathrm{m}$ to & Assay \\
\hline $\mathrm{BH} 1$ & 1 & 17.25 & 17.45 & 29.7 \\
\hline BH1 & 2 & 17.45 & 20.35 & 31.62 \\
\hline BH1 & 3 & 20.35 & 24.60 & 36.54 \\
\hline BH1 & 5 & 26.60 & 28.10 & 39.58 \\
\hline BH1 & 6 & 28.10 & 29.10 & 37.70 \\
\hline
\end{tabular}

The closed strings were digitised and saved. The strings were triangulated and made to form a solid model. The model was validated. This database was used as input in SURPAC software to generate the drill holes, strings, the solid ore body and consequently determine the ore reserve.

The block model of the Ajabanoko iron ore deposit was carried out by creating an empty block model; attributes were added, followed by the constraints. The attributes added are grade, density and lithology. A user block size of $10 \mathrm{~m}$ by $10 \mathrm{~m}$ by $10 \mathrm{~m}$ and minimum size of 5 $\mathrm{m}$ by $5 \mathrm{~m}$ by $5 \mathrm{~m}$ was used to establish the model. The block model was created using grade and lithology constraints. The model was saved as Ajabanoko.mdl. The estimation was done using the inverse distance method as contained in the SURPAC 6.4.1 software.

\section{Results and discussion}

The block model summary of the ore body is presented in Table 4, while the density for Ajabanoko iron ore deposit is 3.65 tonnes $/ \mathrm{m}^{3}$.

\begin{tabular}{lllll}
\multicolumn{5}{c}{ Table 4: Block Model Geometry } \\
\hline Coordinate & Minimum & Maximum & User Block Size $(\mathrm{m})$ & Minimum Block Size $(\mathrm{m})$ \\
\hline Y & $843,977.82$ & $844,927.82$ & 10 & 5 \\
X & $198,905.93$ & $199,405.93$ & 10 & 5 \\
$\mathrm{Z}$ & -147.692 & 302.308 & 10 & 5 \\
\hline
\end{tabular}

The strings, solid ore body, block model and clipped DTM of Ajabanoko ore body are presented in Figures 2, 3, 4 and 5 respectively.

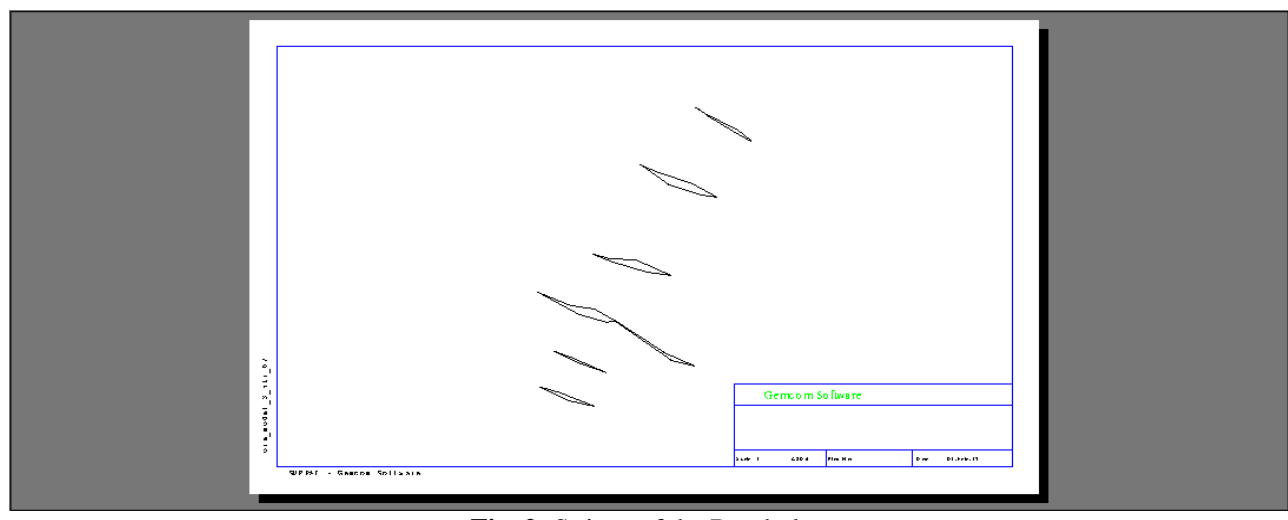

Fig. 2: Strings of the Boreholes.

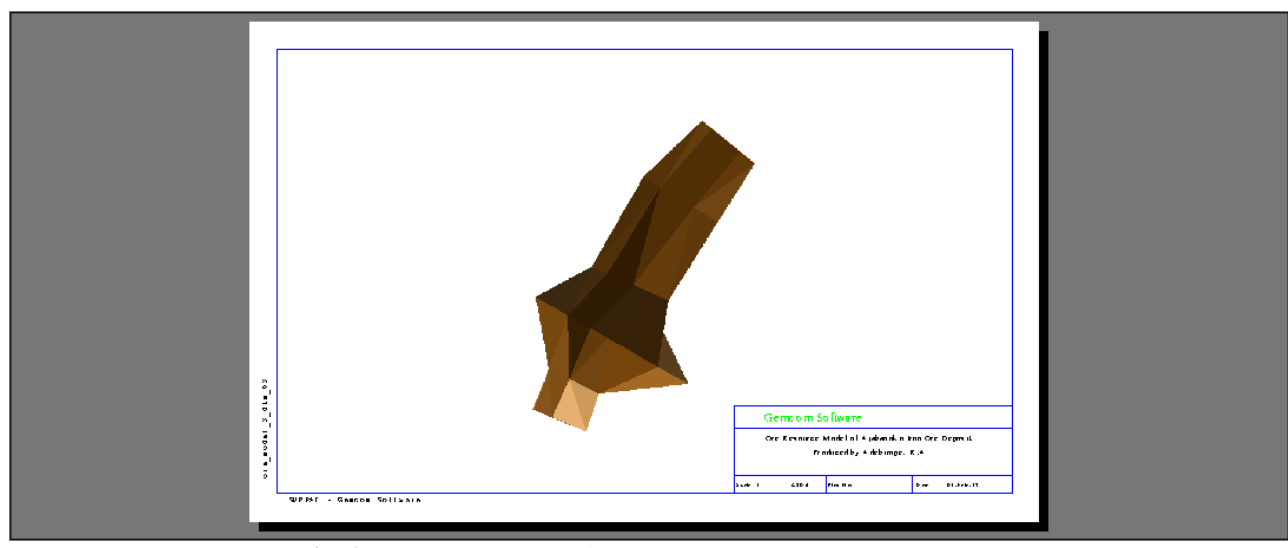

Fig. 3: Resource Model of Central Ajabanoko Iron Ore Deposit 


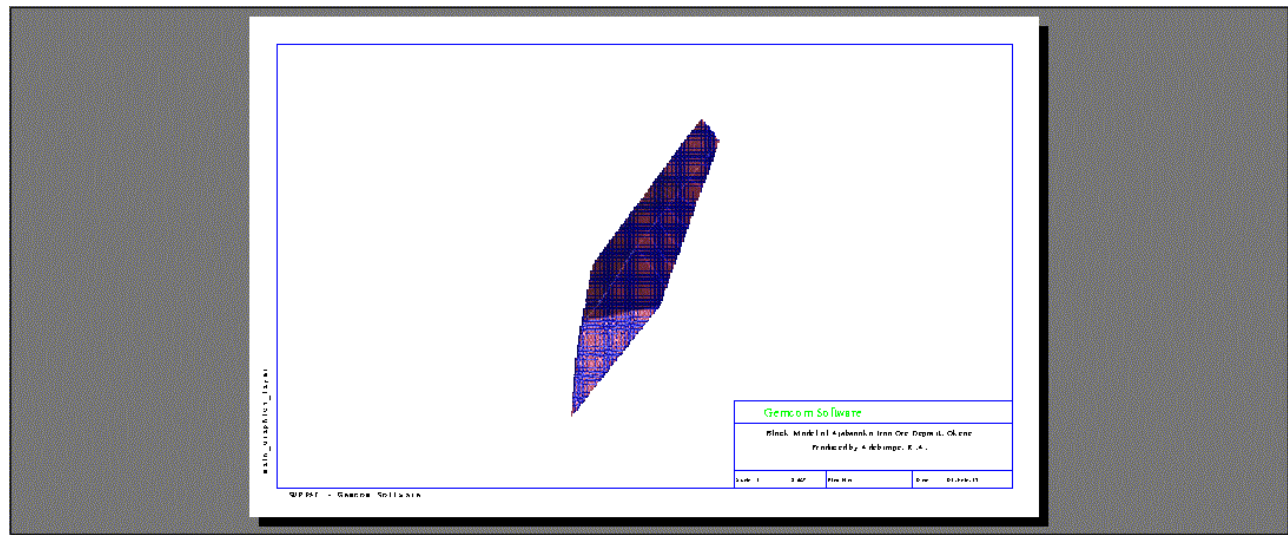

Fig. 4: Block Model of Ajabanoko Iron Ore Deposit.

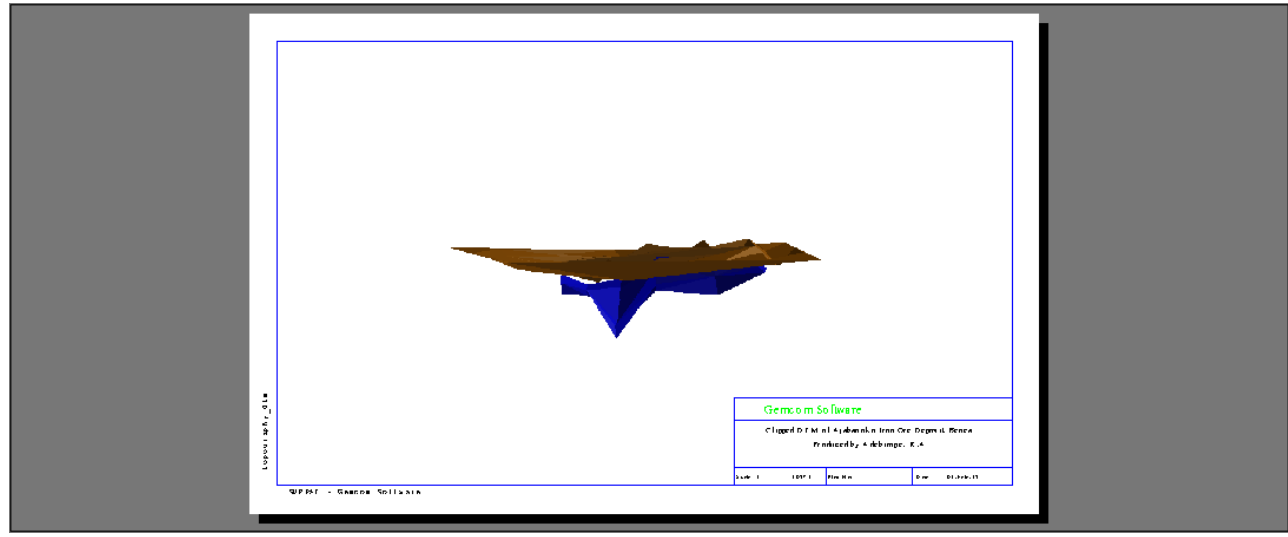

Fig. 5: Clipped DTM of Ajabanoko Iron Ore Deposit.

The borehole data used for the ore body modelling of the Central area of the Ajabanoko iron ore deposit provides a continuous line of geologic information. The ore body resource modelling was carried out using SURPAC software which utilises geological database as input material. The trisolation extents of the ore body indicate a volume of $10,496,595 \mathrm{~m}^{3}$. Result from the ore body model indicates the reserve estimate of 38,313,595 tonnes for the Central region of the deposit (Table 5).

Table 5: Ore Reserve Estimate of Ajabanoko Iron Ore Deposit

\begin{tabular}{|c|c|c|c|c|}
\hline Grade & Lithology & Volume & Tonnes & Grade $(\%)$ \\
\hline $30.0->60.0$ & & $10,496,750$ & $38,313,139$ & 36.36 \\
\hline Sub Total & $\mathrm{Fe}$ & $10,496,750$ & $38,313,139$ & 36.36 \\
\hline $60.0->90.0$ & & 125 & 456 & 67.41 \\
\hline Grand Total & & $10,496,875$ & $38,313,595$ & 36.36 \\
\hline
\end{tabular}

The peak height of the ore body is about $302.308 \mathrm{~m}$ while the minimum depth is $-147.692 \mathrm{~m}$. At an estimated run-of-mine (rom) production rate of 5.021 million tonnes per annum, the lifespan of the deposit is expected to be 7.63 years. The waste to ore ratio is $1.25: 1$ while the daily ore and waste production are 20,921.26 tonnes and 26,152.20 tonnes respectively. The average grade of the ore is $36.36 \%$ which is very close to that of near-by Itakpe iron ore deposit which has a value of $36 \%$.

\section{Conclusion}

The Central area of the Ajabanoko iron ore deposit has a reserve estimate of 38.313 million tonnes and lifespan of 7.63 years at the rate of production of 5.021 million tonnes per annum.

\section{References}

[1] Muhammad, K. N. (2018). Ore Reserve Estimation of Saprolite Nickel Using Inverse Distance Method in PIT Block 3A Banggai Area Central Sulawesi. IOP Conf. Series: Journal of Physics: Conf. Series 979 (2018) 012047. https://doi.org/10.1088/1742-6596/979/1/012047.

[2] Yunsel, T.Y. (2012). A practical application of geostatistical methods to quality and mineral reserve modelling of cement raw materials. The Journal of The Southern African Institute of Mining and Metallurgy. Vol. 12: 239-249.

[3] Chanderman, L. Dohm, C.E and Minnitt, R. C. A. (2017). 3D geological modelling and resource estimation for a gold deposit in Mali. The Journal of the Southern African Institute of Mining and Metallurgy. Vol. 117, p.189. https://doi.org/10.17159/2411-9717/2017/v117n2a10.

[4] Canadian Institute of Mining (2003). Estimation of Mineral Resources and Mineral Reserves. Best Practice Guidelines. CIM,Canada, pp. 55.

[5] Rossi, M.E and Deutsch, C. V. (2014). Mineral Resource Estimation. Springer Science+Business Media Dordrecht. P.29. https://doi.org/10.1007/978-1-4020-5717-5.

[6] Ayisi, Maurice, (2015). 3D Block Modeling and Reserve Estimation of a Garnet Deposit. Graduate Theses \& Non-Theses. 15. http://digitalcommons.mtech.edu/grad_rsch/15.

[7] Saboor, A. T, and Choudhary, B. S (2017). Conventional and Computer Aided Ore Reserve Estimation. International Journal of Engineering Technology Science and Research, IJETSR, 4(12): 896-903. 
[8] Castañón César, Daniel Arias, Isidro Diego, Agustin Martin-Izard and Yhonny Ruiz (2017). Resource and Reserve Calculation in Seam-Shaped Mineral Deposits; A New Approach: "The Pentahedral Method". Minerals 7(72):1-21. https://doi.org/10.3390/min7050072.

[9] Wang, G.; Zhang, S.; Yan, C.; Song, Y.; Li, D. (2011). Mineral potential targeting and resource assessment based on 3D geological modelling in Luanchuan region, China. Comput. Geosci. 2011, 37, 1976-1988. https://doi.org/10.1016/j.cageo.2011.05.007.

[10] Amigun, J.O and Ako, B.D. (2009). Rock Density- A Tool for Mineral Prospection: A Case Study of Ajabanoko Iron Ore Deposit, Okene SW Nigeria. The Pacific Journal of Science and Technology. 10(2):733-741.

[11] Olade, M.A, (1978). Pre Cambrian Iron Ore Deposits and its Environment at Itakpe Ridge, Okene, Nigeria. Institute of Mining and Metallurgy, February. Pp. B1-B9.

[12] National Steel Development Authority (NSDA) (1976). V/O Tecchnoexport: On the Prospecting and Exploration of Itakpe Hill Iron Ore Deposit, Okene, Nigeria. NSDA. Kaduna. Pp. 1-86.

[13] National Steel Raw Materials Exploration Agency (NSRMEA) (1994). Preliminary Report on Ajabanoko Iron Ore Deposit. NSRMEA, Kaduna. Pp. 1-79.

[14] Nnagha, B.I. (1997). Prefeasibilty Study of the Central Zone of the Ajabanoko Hill Iron Deposit. Ecoles des Mines de Paris. Paris. P. 60.

[15] Barton, P.B., Jr., (1993). Problems and opportunities for mineral deposit models, in Kirkham, R.V., Sinclair, W.D., Thorpe, R.I., and Duke, J.M., eds., Mineral deposit modeling: Geological Association of Canada Special Paper 40, p. 7-13.

[16] Henley, S. (2000). Resources, Reserves and Reality. Earth Science Computer Applications. 16,1-2.

[17] Wang Qingfei , Jun Deng, Huan Liu, Liqiang Yang, Li Wan a, Ruizhong Zhang (2010). Fractal Models for Ore Reserve Estimation. Ore Geology Reviews 37 (2010):2-14. https://doi.org/10.1016/j.oregeorev.2009.11.002.

[18] Annels, A.E. (1991). Mineral Deposit Evaluation. A practical approach. Chapman \& Hall London. Pp. 449. 